\title{
Leadership in the Research: Determinants of Quality, Standards and Best Practices
}

\author{
http://doi.org/10.21272/bel.5(1).45-56.2021
}

Henryk Dźwigol, ORCID: https://orcid.org/0000-0002-2005-0078

Doctor of Economics, Professor, Silesian University of Technology, Gliwice, Poland; Professor, London Academy of Science and Business, London, United Kingdom; Professor, Sumy State University, Sumy, Ukraine

\begin{abstract}
One of the obligatory elements of any scientific research is a methodical toolkit, the diversity of which determines the reliability of the obtained results and ability to solve the tasks set in the work. The purpose of the article is to identify the factors defining the scientific research process and affect the quality of the results. The methodological tools of the study include questionnaires and factor analysis (Bartlett's test for sphericity, KMO test (Kaiser-Meyer-Olkin sampling adequacy measure), and MSA test (sampling adequacy measure)). The object of research is 401 scientists and 196 practitioners in the field of management and quality sciences. The questionnaire for practitioners consisted of four parts. The first part includes general issues about the research process, methods and techniques used in it; the second deals with the importance of using methods and techniques in the scientific research in the field of management and quality sciences; the third - provides questions on improving the quality of research; the fourth is demographic. The questionnaire for scientists consists of three parts. The first part addresses the importance of approaches, processes, methods and techniques in research in the field of management and quality sciences; the second - includes questions on improving the research process; the third is demographic. The results are summarized on a five-point Likert scale. Based on the generalization of practitioners' answers, the main factor of scientific research is the "concept of the research methodology model", defined as a measure of the scientific research process effectiveness. The results of the analysis help conclude the need to develop new research methods that can increase its effectiveness by managing, planning, organizing and verifying the research process in the field of management and quality sciences. The factors determining the research process and affecting its quality include constant changes in the market. It necessitates the use of various research methods that can form a holistic basis for empirical analysis. The research process quality means checking the degree of implementation and consistency of the objectives in the article with the research problem and the conclusions in it. For the effective functioning of the research process, it is proposed to develop an "algorithm of behavior" of the researcher, which will (after determining the appropriate gap between research methods and features of the research problem) ensure their coordination and increase the added value of the results.
\end{abstract}

Keywords: Research Process, Determinants, Choice of Methods, Leadership, Quality, Quantity.

JEL Classification: C00, M50.

Cite as: Dźwigoł, H. (2021). Leadership in the Research: Determinants of Quality, Standards and Best Practices. Business Ethics and Leadership, 5(1), 45-56. http://doi.org/10.21272/bel.5(1).45-56.2021.

Received: 25 January 2021

Accepted: 10 March 2021

Published: 30 March 2021

Copyright: (C) 2021 by the author. Licensee Sumy State University, Ukraine. This article is an open access article distributed under the terms and conditions of the Creative Commons Attribution (CC BY) license (https://creativecommons.org/licenses/by/4.0/).

\section{Introduction}

The methodology of scientific research is of fundamental importance in the light of the knowledge of the methods used in the creation of scientific studies, such as articles, doctoral theses, or MA/BA theses. It includes the analysis of the methods or instruments necessary for the development of scientific work (Queiros, Faria, and Almeida, 2017). Gutting (Gutting, 2017) indicates that, in essence, the scientific methodology refers to any generalized and systematically developed procedures that can turn out to be successful in science. According to Flanagan (Flanagan, 2013), a scientific methodology is a key tool for discovering new theories and conducting their empirical verification. Therefore, scientific research is a process of systematic and intensive research that aims at discovering and interpreting facts introduced into a specific reality. With respect to this approach, scientific research can be either qualitative or quantitative. Regardless of the qualitative or 
quantitative nature of the research - scientists still discuss the validity of its application. However, as Choy (Choy, 2014) states, there is no perfect distinction between qualitative and quantitative approaches, and the literature still highlights the strengths and weaknesses of both approaches. The author also points out that a better solution can be achieved by merging both approaches - qualitative and quantitative. He also indicates that this may be an alternative way to provide a better research methodology solution. In this context, Neuman (Neuman, 2006) also emphasizes that conducting scientific research requires a decision on the type of sample or case under analysis. This decision makes it possible to measure relevant factors and the research techniques such as the questionnaires or experiments to be used. Nowadays, in the sciences of management and quality, various types of rules, procedures, and tools are being developed that make it possible to deepen the knowledge of the existing problem situation compared to the traditional approach (Ares and Varela, 2018). Taking this into account, one must ask, what will affect the quality of the research process?

\section{Literature Review}

The discipline of management and quality sciences is characterized by a high self-criticism level (Hatchuel, 2005). Researchers are also criticized here for the methodological rigor of the said discipline. The authors mainly point out the lack of a reliable measurement tool (Govindarajan and Kopalle, 2006), the overdevelopment of theories with underdeveloped operationalization (Venkatraman and Grant, 1986), unclear empirical embedding (Danneels, 2016), and conceptual vagueness (Gatignon et al., 2002). Shrivastava (Shrivastava, 1987) indicates that methodological evaluation of studies can be carried out based on three dimensions:

$>$ Conceptual adequacy concerning the correctness of embedding the study within the theoretical framework of a specific discipline.

$>$ Methodological rigor referring to the design and applied research method.

> Accumulated empirical material, which allows the confirmation and substantiation of the results obtained.

Terpsta (Terpsta, 1982) indicates the following criteria for assessing the methodological rigor of research on organizational development:

$>$ Research, descriptive, or testing strategy.

$>$ Representative or non-representative choice of samples.

$>$ Measurement characteristics.

$>$ The use of control groups.

$>$ The advancement of statistical data processing techniques.

Woodman and Wayne (Woodman and Wayne, 1985) add to this the type of dependent variable, the sample size, factor analysis, and measures of reliability and relevance. Chen et al. (Chen et al., 2007) also point out that managers' participation is essential to learn about the causes and course of processes, as well as their consequences, in the sciences of management and quality. The behavior of an organization results from its decisions, which in turn are the result of the organization and its perception of the outside world. Nowadays, the external world is strongly connected to the 4.0 Industry, which is seen as the beginning of a new era in which industry becomes "smarter and smarter" using the Internet of Things, intensive data exchange and predictive analyses (Porter and Heppelmann, 2015; Lenka, Parida and Wincent, 2017). That is why modern managers should bear in mind that most companies from a wide array of industries are entering the Fourth Industrial Revolution that is changing the way businesses operate, which is directly related to performance (Imran, Waseem and Adnan, 2018; Rüßmann et al., 2015; Waschneck et al., 2016; Dźwigoł et al., 2020a; 2020b; Dementyev and Kwilinski A., 2020) and affects the entire value chain within the industry (Iansiti and Lakhani, 2014; Cenamor, Sjödin and Parida, 2017; Bogachov et al., 2020; Dzwigoł and Dzwigoł-Barosz, 2020; Kwilinski et al., 2020; Boiko et al., 2019; Chygryn et al., 2020; Czyżewski et al., 2019; Cyfert et al., 2020; Czakon et al., 2020; Dalevska et al., 2019; Dyduch 2019a; 2019b; Gorynia, 2019; Gorynia et al., 2019; Kharazishvili et al., 2020; Klimas et al., 2020; Kwilinski, 2017; 2018a; 2018b; 2018c; 2019; Kwilinski et al., 2019a; 2019b; 2019c; Kyrylov et al., 2020; Lakhno et al., 2018; Lyulyov et al., 2021; Miśkiewicz, 2018; 2019; 2020a; 2020b; Miśkiewicz and Wolniak, 2020; Pająk et al., 2016; 2017; Saługa et al., 2020; Savchenko et al., 2019; Tkachenko et al., 2019a; 2019b; 2019c; 2019d; Trąpczyński et al., 2019; Zastempowski, 2020), including the way the research process is conducted. What is more, today's industrial development is determined not only by the availability of natural resources, but also by intellectual potential and the ability to implement innovations in scientific and technological progress (Dźwigoł et al., 2019a; 2019b; Dźwigoł, 2019a; 2019b; 2020a; 2020b; 2020c).

The research process performed in all branches consists of fixed elements, i.e., analysis and synthesis. The contribution of elements depends on the character of the phenomena being examined. One can therefore conclude that empirical research methods are appropriate methods in the management and quality sciences. 
Deductive methods and analogical reasoning complemented by managerial intuition should be a source of research hypotheses (Dźwigoł and Dźwigoł-Barosz, 2018) as well as a basis for formulating research questions. Furthermore, Weick (Weick, 1989) indicates that for the research process to be described as authentic, the following criteria must be identified: (1) the social selection criterion and (2) the evaluation criterion in terms of theoretical proposals. It is necessary to complement the process of comparing research results with an objective criterion of truth. It is also crucial to focus on the relationship between the rese arch subject and the opinions expressed by key players in the academic community. The players' support makes it possible to achieve a highly appreciated scientific authenticity. The author emphasizes that the basic criterion for assessing the authentic character of the research process is its credibility. The latter might be particularly reinforced using such statements as "it is interesting", "it is obvious", "it is meaningless," or "it is absurd". Conclusions resulting from the above-described analysis of domestic and foreign literature, indicate the need to analyze the problem, i.e., to identify what factors determine the quality of the research process.

\section{Methodology}

Quantitative research is conducted using a survey questionnaire and factor analysis to identify the factors determining the research process in the management and quality sciences. The survey questionnaire was addressed to scientists and practitioners in management and quality sciences, for whom two separate questionnaires were developed. The scientists submitted 401 correctly completed questionnaires that formed the basis for further analysis, whereas practitioners submitted 196 questionnaires. The questionnaire addressed to the practitioners researching within the framework of basic management activities consisted of four parts: the first one included general questions about conducting research and using available methods and techniques in practice (6 questions); the second one was devoted to the importance of using methods and techniques in the research process in the management and quality sciences ( 2 questions); the third one consisted of questions about improving the level of conducted research processes (4 questions), while the fourth one included demographics (5 questions). The questions were evaluated based on the five-stage Likert scale (4 questions), thanks to which the time to fill in the questionnaire was optimal. The questionnaire addressed to the scientists consisted of three parts, where the first part was made up of questions concerning the significance of approaches, processes, methods, and techniques in the research process in the management and quality sciences (5 questions), the second part included questions concerning the raised problem of research process improvement (33 questions), and the third part involved demographics (3 questions). The questions in the questionnaire were evaluated based on the five-grade Likert scale, thanks to which the time of its completion was optimal.

During the factor analysis, the following methods were used:

the Bartlett's test of sphericity.

$>$ The KMO (Kaiser-Meyer-Olkin Measure of Sampling Adequacy) measure and the MSA (Measure of Sampling Adequacy) measure.

In Bartlett's test of sphericity, it was verified whether the matrix of the Pearson correlation coefficient is not a unit matrix. The null hypothesis of this test is "The matrix containing correlations of variables is a unit matrix," which does not allow the factor analysis to be carried out. The alternative hypothesis is put in the form of a denying sentence: "A matrix containing correlations of variables is not a unit matrix". A test statistic was calculated that depended on the number of variables, the correlation matrix determinant, and the number of variable observations. The test statistic has a chi-square distribution. The results of the test discussed above are shown in Table 1.

Table 1. The Bartlett's Test (of sphericity) (results are relevant when $\mathrm{p}<0.05$ )

\begin{tabular}{|c|c|c|c|}
\hline Empirical chi & Levels of freedom & p-value & Theoretical chi $^{\mathbf{2}}$ \\
\hline 4830.794 & 528 & $<\mathbf{0 . 0 0 1}$ & 582.564 \\
\hline
\end{tabular}

Source: The author's work based on (Dźwigoł, 2018).

The results in Table 1 show that the empirical chi $^{2}$ is larger than the theoretical chi $^{2}$ (we reject the null hypothesis in favor of the alternative), which means that the variables are suitable for factor analysis. The KMO measure in the analyzed case is 0.835 . It is between 0 and 1 , which means that factor analysis is justified in this analysis. The more accurate test is the MSA Measure since it is defined for each question (variable). Table 2 presents the results of the analyzed case. 
Table 2. The MSA Measure

\begin{tabular}{|c|c|}
\hline Variable no. & MSA \\
\hline P6 & 0.850 \\
\hline P7 & 0.805 \\
\hline P8 & 0.818 \\
\hline P9 & 0.869 \\
\hline P10 & 0.852 \\
\hline P11 & 0.883 \\
\hline P12 & 0.846 \\
\hline P13 & 0.817 \\
\hline P14 & 0.790 \\
\hline P15 & 0.786 \\
\hline P16 & 0.873 \\
\hline P17 & 0.909 \\
\hline P18 & 0.794 \\
\hline P19 & 0.802 \\
\hline P20 & 0.865 \\
\hline P21 & 0.860 \\
\hline P22 & 0.875 \\
\hline P23 & 0.885 \\
\hline P24 & 0,701 \\
\hline $\mathrm{P} 25$ & 0.720 \\
\hline P26 & 0.862 \\
\hline P27 & 0.884 \\
\hline P28 & 0.884 \\
\hline P29 & 0.845 \\
\hline P30 & 0.823 \\
\hline P31 & 0.840 \\
\hline P32 & 0.801 \\
\hline P33 & 0.856 \\
\hline P34 & 0.843 \\
\hline P35 & 0.813 \\
\hline P36 & 0.849 \\
\hline P37 & 0.794 \\
\hline P38 & 0.766 \\
\hline
\end{tabular}

Source: The author's work based on (Dźwigoł, 2018).

If the MSA coefficient for a given question is lower than 0.5 , one should consider removing the said variable from the analysis. According to Table 2, the MSA coefficient for each of the questions is greater than 0.5. Thus, all the problems may be subject to further analysis. In the present research, the condition concerning the number of observations was also met, namely that they should be at least two times greater than the number of variables. Therefore, all the requirements for factor analysis were satisfied.

\section{Findings}

The factor analysis involves selecting the so-called factors. These factors describe determinants that are common for a central determinant. In this case, the research process is regarded as the main determinant. A consequence of selecting the said analysis is the transformation of observations, which was presented in Figure 1.

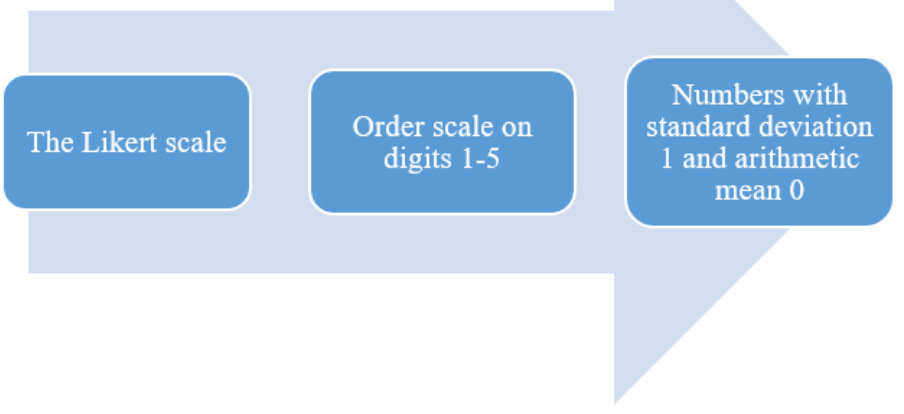

Figure 1. Process of Transforming the Likert Scale into "Factor Observations"

Source: The author's work based on (Dźwigoł, 2018). 
Each selected factor needs to meet the so-called Kaiser criterion (its value is greater than 1). In this case, the phenomenon explanation level by a given factor is the ratio of its auto-value to the number of variables. These factors may correspond to the number mentioned in the literature. They do not have to since the constant development of the management and quality sciences is natural and desirable. The rigid adherence to the factors described in the literature often results in the shallowness of the research problem they represent. The Scree Chart (Fig. 2) is a graphic representation of factors fulfilling the said condition.

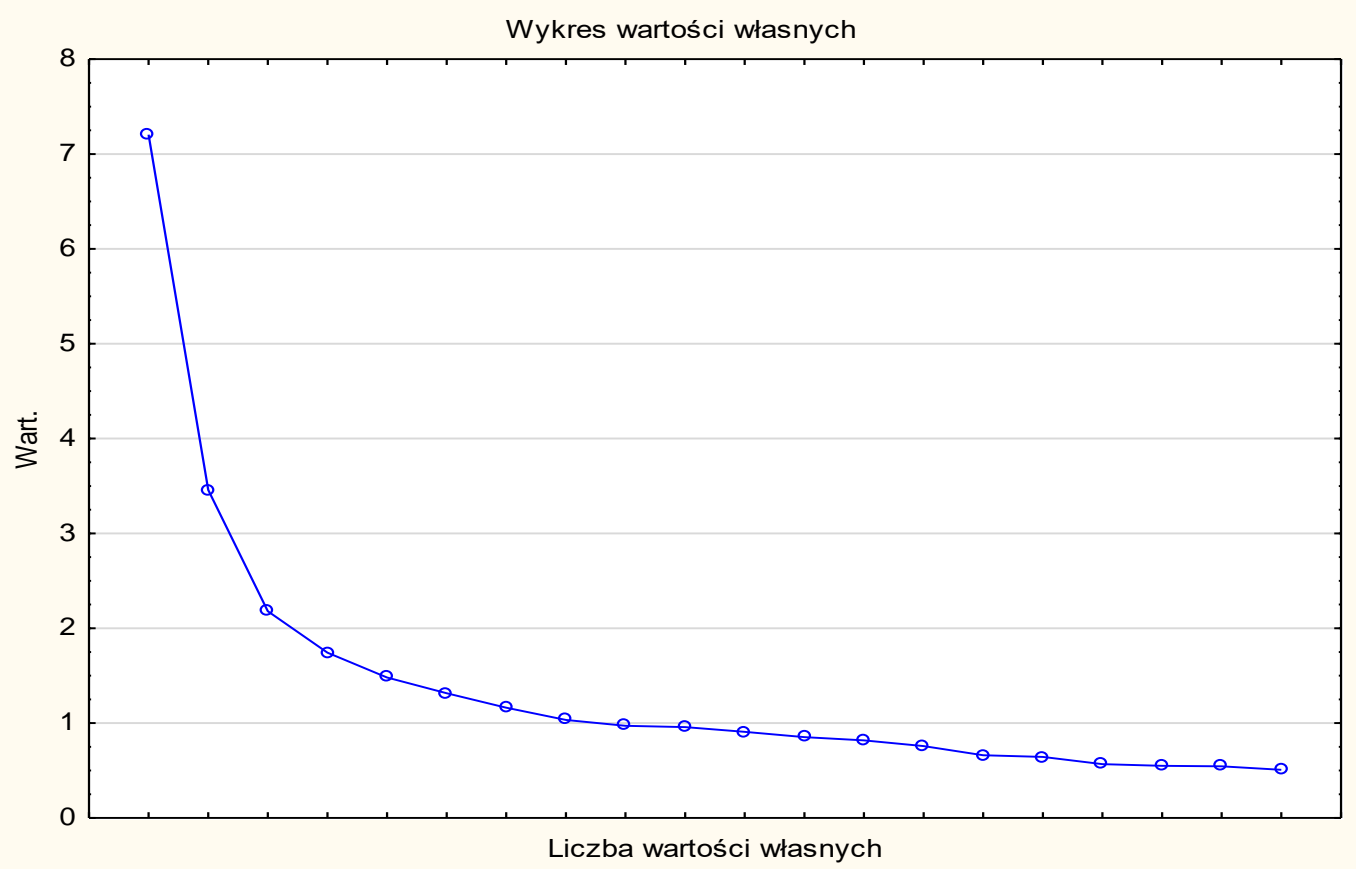

Figure 2. "Scree"

Source: The author's work based on (Dźwigoł, 2018).

Based on the analysis of Figure 2, one can conclude that 8 factors meet the mentioned Kaiser criterion. This number of factors is sufficient to illustrate the problem. The combination of the questions is done by means of the so-called factor loads. When the value of a factor load is greater than 0.55 , it is considered that the question is sufficiently well-described by this factor (Szcucka, 2010). Moreover, if one of the questions has a negative factor load, it means that a failure to apply it will cause the central variable score to deteriorate. It should also be remembered that the overriding criterion for selecting the number of factors should be their interpretability. If the researcher concludes that the number of methodologically interpretable factors is lower than the mathematically determined ones, he/she should choose those that have a higher level of explained variance of the central variable.

In parallel to deciding on the number of factors, one should determine their rotation, i.e., the type of axis rotation. The rotation can be orthogonal (at right angles) or diagonal (non-orthogonal). There are three kinds of orthogonal rotations:

VARIMAX - a standard method; it reduces the number of variables with high loads on each factor; thus, the factor interpretation is facilitated;

QUARTIMAX - it reduces the number of factors necessary to explain a given variable, it enables the interpretation of variables in terms of factors;

EQUAMAX - is a combination of the two methods mentioned above; it facilitates the interpretation of both variables and factors.

The choice of a given rotation depends on the researcher and it should be remembered that it is the researcher, not the statistics, who interprets the factors. Statistics is only a sort of assistance in directing the examined phenomenon from the coherence of its mathematical assumptions. One should bear in mind that choosing a particular rotation, the influence of a given factor on the described problem changes to reduce differences between them. The total level of the explained phenomenon does not change. In the case in question, one can explain 59.32\% of the research process using eight defined factors. Figure 3 shows determinants of the research process, as defined through the EQUAMAX rotation. 


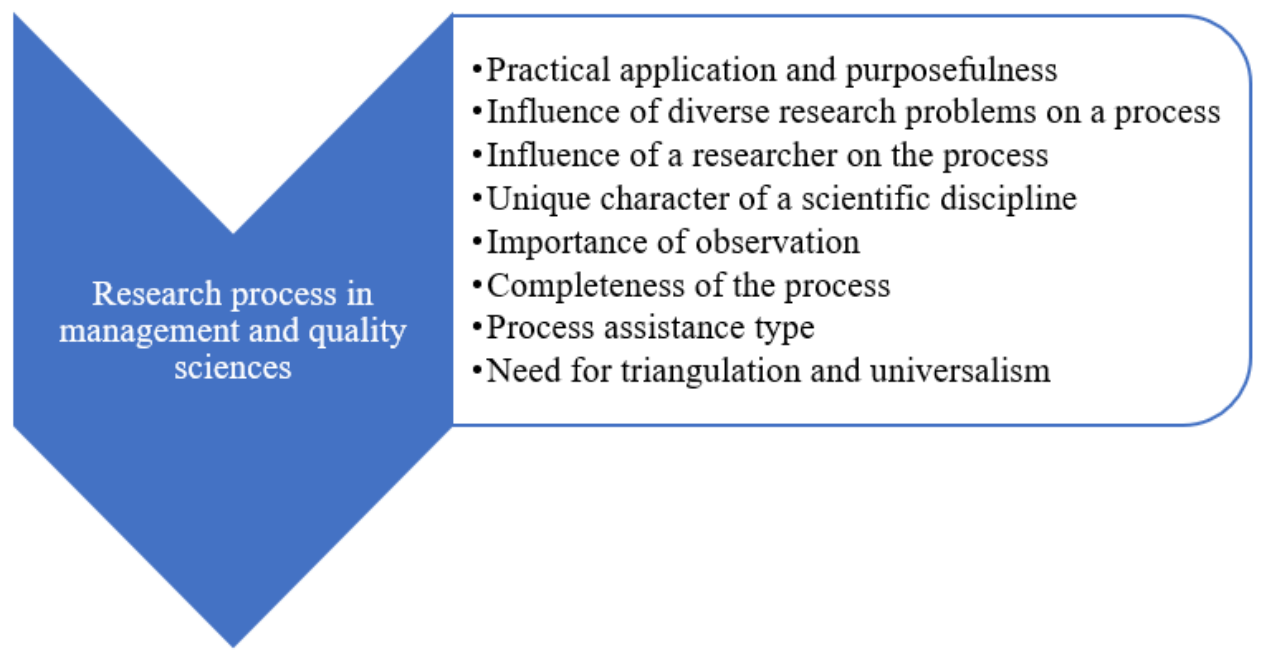

Figure 3. Determinants of the Research Process

Source: The author's work based on (Dźwigoł, 2018).

The "Practical application and purposefulness" factor consists of 4 questions (6-9) from the survey questionnaire. The factor is an opportunity to fulfill a scientific target, i.e., an ability to implement the research process in question into companies' operation, into real economic life, or into the cooperation of a team of people.

The "Influence of diverse research problems on the process" factor covers six questions $(10-13,16,35)$. It is understood as an answer to the question about the extent to which the selected research problem will determine researchers' further actions. The factor "Influence of a researcher" covers three questions (24-26). It is associated with the scope of free decisions taken by the researcher while dealing with a problem. The factor "Unique character of scientific discipline" covers two questions (14 and 15) and shows differences in how practitioners and theoreticians evaluate the selected methods, which makes it difficult to assess, in an objective way, the verifiability of the conducted research studies.

The "Importance of observation" factor shows the impact of two types of observation. The first type of observation deals with the opportunity to cooperate with other entities; the second type involves the observation followed by a possible intervention. The factor covers two questions (37 and 38). The "completeness of the process" factor consists of 3 questions (29-31). The factor is understood as an opportunity to divide the research process into stages that form a complementary whole. The stages are as follows:

combining qualitative and quantitative methods;

$>$ elaborating a unique tool, model, approach to the way a method or procedure is selected;

$>$ indicating recommendations as to scientific and practical aspects.

The "supported process" factor consists of three questions $(20,22,26)$. It is understood as an impact on the course and management of the research process using pilot studies and case studies. The last factor identified is the need for the triangulation and universalism of the conducted research $(18,19)$. This requirement has been partially enforced by the continuous improvement of management and quality sciences; however, a failure to meet it does not always translate into an authentic solution to the research problem. It should be emphasized that some of the 33 questions $(16,21,23,27,28,32,33,35)$ conveyed similar information about the process and have not found their equivalents among these factors. Additionally, these questions have not met the mentioned criterion of factor load.

In the group of practitioners, it was also agreed to apply factor analysis to questions 9-12 derived from the said survey questionnaire. These questions have also been structured on the Likert scale and, have been converted into the scale 1-5 as with theoreticians for further analysis. As these questions relate to the effectiveness of the research process in practice, this issue has been called the central variable. Having applied the factor analysis, it turned out that the central variable consists of 1 factor, which in $94 \%$ explains the functioning of the research process in practice. The factor consists of all the mentioned questions (9-12), and each of the questions meets the criterion of the value of the factor load. These questions from the survey questionnaire form a common factor called the "concept of the research methodology model". The factor loads of the questions from the questionnaire have a negative value, which practically means that a failure to comply with the statements contained therein prevents the creation of added value in the work. 


\section{Discussion}

The primary goal of the research process is to develop new knowledge. This process should be both theoretical and empirical. As the initial point of the research, the theoretical process is conceptualizing the research topic and developing research questions and hypotheses. Empirical, because all the research planned within the process includes observations, measurements, or data analysis (Reisman, 2011; Bartz, 2011; Balakumar and Jagadeesh, 2012). Providing the research with theoretical and empirical aspects by the researcher is one of the key factors affecting its quality. Moreover, continuous changes in the market determine the research process and affect its quality, especially in the management and quality sciences.

Hence, it must be said that it is necessary to apply diverse research methods in the research process to obtain a coherent basis for empirical inference (Dzwigol, 2020). It should be emphasized that in social sciences, it is a mistake to apply only one research method appropriate for a given research topic (Dzwigol, 2020). The results of numerous authors' reflections (e.g., Quach et al., 2019; Avila-Robinson and Wakabayashi, 2018; Cunningham and Wallraven, 2011) show that it is necessary to combine qualitative and quantitative research methods within the research process (Dzwigol and Wolniak, 2018). It is because it significantly determines the quality of the research process.

Moreover, as the European Science Foundation (European Science Foundation, 2012) highlights, assessing the quality of research practice is an essential issue in most scientific fields and at many levels. In this context, Martensson et al. (Martensson et al., 2016) point out that there are no "better" or "worse" research methods. According to the authors, virtually any scientific method may be appropriately provided it considers a properly planned research process. These research questions should assist decision-making for research design and about which methods to use. One may indicate, as another determinant of the quality of the research process, the adaptation of the research method to the conducted research process and the use of these methods with rigor. Martensson et al. add that theories can be perceived as "maps" and research methods as "networks". Both theories and research methods are highly context-dependent in terms of the way they detect and capture elements to create new knowledge.

\section{Conclusions}

It should be borne in mind that, depending on the subject matter undertaken by the researcher in his/her doctoral or post-doctoral thesis, some of the factors mentioned herein may not necessarily find their reflection, thereby diminishing its importance in science and practice. The determinants of the quality of the research process mentioned in the article are the benchmarks enabling the assessment of the quality of the research process carried out. The concept of the quality of the research process in management and quality sciences is understood as the possibility of verifying the degree of implementation and coherence of paper goals with the research problem and conclusions described herein. Moreover, it should be emphasized that it is necessary to develop a kind of "algorithm of conduct" for the effective functioning of the research process. The latter will allow the adjustment of methods to the research problem upon prior definition of a gap, which will result in the added value of the work for the practice. One can distinguish the following types of added value for practice within management science: model, procedure, recommendation, and tool. Should at least one of these types be well-developed, it shall result in a visible improvement of cooperation between theory and practice in modern business. The analysis of practitioners' answers has revealed that a factor explains the functioning of the research process in practice called the "concept of the research methodology model". This concept is understood as a measure of the effectiveness of the research process, and it can be noticed that to increase its efficiency, it is necessary to elaborate a model of research methods. The model of research methods would facilitate the proper managing, planning, organizing, and inspecting of the research process in the management and quality sciences.

Funding. There is no funding for this research.

\section{References}

1. Ares, G., Varela, P. (Eds). (2018). Methods in Consumer Research (Vol. 1): New Approaches to Classic Methods, Woodhead Publishing, Elsevier, Duxford, UK. https://doi.org/10.1016/B978-0-08-1020890.05001-9.

2. Ares, G., Varela, P. (Eds). (2018). Methods in Consumer Research (Vol. 2): Alternative Approaches and Special Applications, Woodhead Publishing, Elsevier, Duxford, UK. https://doi.org/10.1016/B978-0-08101743-2.05001-9. 
3. Avila-Robinson, A., \& Wakabayashi, N. (2018). Changes in the structures and directions of destination management and marketing research: A bibliometric mapping study, 2005-2016. Journal of Destination Marketing \& Management, 10, 101-111. https://doi.org/10.1016/j.jdmm.2018.06.005.

4. Bartz, C.C. (2011). Getting Started with Research: Ideas to Research Process. RGUHS Journal of Pharmaceutical Sciences, 1(3), 176-179. https://doi.org/10.5530/rjps.2011.3.1.

5. Balakumar, P., Jagadeesh, G. (2012). The basic concepts of scientific research and scientific communication. J Pharmacol Pharmacother, 3, 178-82. https://doi.org/10.4103/0976-500X.95522.

6. Bogachov, S., Kwilinski, A., Miethlich, B., Bartosova, V., Gurnak, A. (2020). Artificial Intelligence Components and Fuzzy Regulators in Entrepreneurship Development. Entrepreneurship and Sustainability Issues, 8(2), 487-499. http://doi.org/10.9770/jesi.2020.8.2(29).

7. Boiko, V., Kwilinski, A., Misiuk, M., Boiko, L. (2019). Competitive Advantages of Wholesale Markets of Agricultural Products as a Type of Entrepreneurial Activity: The Experience of Ukraine and Poland. Economic Annals-XXI, 175(1-2), 68-72. https://doi.org/10.21003/ea.V175-12.

8. Cunningham, D.W., \& Wallraven, C. (2011). Experimental design: From user studies to psychophysics. CRC Press. https://doi.org/10.1201/b11308.

9. Cenamor, J., Sjödin, D.R., Parida, V. (2017). Adopting a platform approach in servitization: Leveraging the value of digitalization. International Journal of Production Economics, 192, 54-65. https://doi.org/10.1016/j.ijpe.2016.12.033.

10.Chen, M.J., Su, K.H., Tsai, W. (2007). Competitive Tension: The Awareness-motivation-capability Perspective. Academy of Management Journal, 50(1), 101-118. https://doi.org/10.5465/amj.2007.24162081.

11.Choy, L.T. (2204). The Strengths and Weaknesses of Research Methodology: Comparison and Complimentary between Qualitative and Quantitative Approaches. IOSR Journal of Humanities and Social Science (IOSR-JHSS), 19(4), 99-104. https://doi.org/10.9790/0837-194399104.

12.Chygryn, O., Bilan, Y., Kwilinski, A. (2020). Stakeholders of Green Competitiveness: Innovative Approaches for Creating Communicative System. Marketing and Management of Innovations, 3, 356-368. https://doi.org/10.21272/mmi.2020.3-26.

13.Czyżewski, B., Matuszczak, A., Miskiewicz, R. (2019). Public Goods Versus the Farm Price-Cost Squeeze: Shaping the Sustainability of the EU's Common Agricultural Policy. Technological and Economic Development of Economy, 25(1), 82-102. https://doi.org/10.3846/tede.2019.7449.

14.Cyfert, S., Glabiszewski, W., Krzakiewicz, K., Zastempowski, M. (2020). The Importance of Dynamic Capabilities in the Processes of Alignment of Chemical Industry Enterprises to Changes in the Environment. Przemysl Chemiczny, 99(6), 953-956. https://doi.org/10.15199/62.2020.6.24.

15.Czakon, W., Kawa, A., Scott, S. (2020). Network Orientation of Logistics Service Providers: The Construct, Dimensionality and Measurement Scale. International Journal of Logistics Research and Applications, 23(5), 474-492. https://doi.org/10.1080/13675567.2019.1705260.

16.Dalevska, N., Khobta, V., Kwilinski, A., \& Kravchenko, S. (2019). A Model for Estimating Social and Economic Indicators of Sustainable Development. Entrepreneurship and Sustainability Issues, 6(4), 1839-1860. https://doi.org/10.9770/jesi.2019.6.4(21).

17.Danneels, E. (2016). Survey Measures of First-and Second-order Competences. Strategic Management Journal, 37(10), 2174-2188. https://doi.org/10.1002/smj.2428.

18.Dementyev, V.V., Kwilinski, A. (2020). Institutional Component of Production Costs. Journal of Institutional Studies, 12(1), 100-116. https://doi.org/10.17835/2076-6297.2020.12.1.100-116.

19.Dyduch, W. (2019). Entrepreneurial Strategy Stimulating Value Creation: Conceptual Findings and Some Empirical Tests. Entrepreneurial Business and Economics Review, 7(3), 65-82. https://doi.org/10.15678/EBER.2019.070304.

20.Dyduch, W. (2019). Organizational Design Supporting Innovativeness. Przeglad Organizacji, 6, 16-23. https://doi.org/10.33141/po.2019.06.02.

21.Dźwigoł, H., Dźwigoł-Barosz, M. (2018). Scientific Research Methodology in Management Science. Financial and Credit Activity: Problems of Theory and Practice, 2(25), 424-437, https://doi.org/10.18371/fcaptp.v2i25.136508.

22.Dzwigol, H., Dzwigol-Barosz, M. (2020). Sustainable Development of the Company on the Basis of Expert Assessment of the Investment Strategy. Academy of Strategic Management Journal, 19(5), 1-7. Available at:

https://www.researchgate.net/publication/348443019_SUSTAINABLE_DEVELOPMENT_OF_THE_C OMPANY_ON_THE_BASIS_OF_EXPERT_ASSESSMENT_OF_THE_INVESTMENT_STRATEGY. 
23.Dźwigoł, H. (2018). Współczesne procesy badawcze w naukach o zarządzaniu. Uwarunkowania metodyczne i metodologiczne [Modern Research Processes in Management Sciences. Methodological and Methodical Conditions, in Polish], PWN, Warszawa. 612 p. Available at: https://www.taniaksiazka.pl/wspolczesne-procesy-badawcze-w-naukach-o-zarzadzaniu-henryk-dzwigolp-1183381.html.

24.Dźwigoł, H. (2019a). Research Methods and Techniques in New Management Trends: Research Results. Virtual Economics, 2(1), 31-48. https://doi.org/10.34021/ve.2019.02.01(2).

25.Dzwigol, H. (2019b). The Concept of the System Approach of the Enterprise Restructuring Process. Virtual Economics, 2(4), 46-70. https://doi.org/10.34021/ve.2019.02.04(3).

26.Dzwigoł, H. (2020a). Innovation in Marketing Research: Quantitative and Qualitative Analysis. Marketing and Management of Innovations, 1, 128-135. http://doi.org/10.21272/mmi.2020.1-10.

27.Dzwigoł, H. (2020b). Methodological and Empirical Platform of Triangulation in Strategic Management. Academy of Strategic Management Journal, 19(4), 1-8. Available at: https://www.abacademies.org/articles/methodological-and-empirical-platform-of-triangulation-instrategic-management-9364.html.

28.Dźwigoł, H. (2020c). Interim Management as a New Approach to the Company Management. Review of Business and Economics Studies, 8(1), 20-26. https://doi.org/10.26794/2308-944X-2020-8-1-20-26.

29.Dźwigoł, H., Dźwigoł-Barosz, M., Zhyvko, Z., Miśkiewicz, R., Pushak, H. (2019a). Evaluation of the Energy Security as a Component of National Security of the Country. Journal of Security and Sustainability Issues, 8(3), 307-317. https://doi.org/10.9770/jssi.2019.8.3(2).

30.Dźwigoł, H., Shcherbak, S., Semikina, M., Vinichenko, O., Vasiuta, V. (2019b). Formation of Strategic Change Management System at an Enterprise. Academy of Strategic Management Journal, 18(1), 1-8. Available at: https://www.abacademies.org/articles/formation-of-strategic-change-management-systemat-an-enterprise-8912.html.

31.Dzwigoł, H., Dzwigol-Barosz, M., Miskiewicz, R., Kwilinski, A. (2020a). Manager Competency Assessment Model in the Conditions of Industry 4.0. Entrepreneurship and Sustainability Issues, 7(4), 2630-2644. https://doi.org/10.9770/jesi.2020.7.4(5).

32.Dzwigoł, H., Dzwigol-Barosz, M., Kwilinski, A. (2020b). Formation of Global Competitive Enterprise Environment Based on Industry 4.0 Concept. International Journal of Entrepreneurship, 24(1), 1-5. Available at: https://www.abacademies.org/articles/formation-of-global-competitive-enterpriseenvironment-based-on-industry-40-concept-9079.html.

33.Dźwigoł, H., Wolniak, R. (2018). Controlling w procesie zarządzania chemicznym przedsiębiorstwem produkcyjnym, [Controlling in the management process of a chemical industry production company]. Przemyst Chemiczny, 97(7), 1114-1116. https://doi.org/10.15199/62.2018.7.15.

34.Evaluation in research and research funding organisations: European practices (2012). A report by the ESF Member Organisation Forum on Evaluation of Publicly Funded Research, 978-2-918428-83-1. Available at:http://archives.esf.org/index.php?eID=tx_nawsecuredl\&u=0\&g=0\&t=1615924654\&hash=413ccd96e2 $\underline{\text { 8c1ee958dc4e940bb2e36871e36ec1\&file=/fileadmin/be user/CEO Unit/MO FORA/MOFORUM Eval }}$ _PFR_II_Publications/mof_evaluation_final.pdf.

35.Flanagan, T. (2013). The scientific method and why it matters. C2C Journal, 7(1), 4-6. Available at: https://c2cjournal.ca/2013/01/the-scientific-method-and-why-it-matters/.

36.Gatignon, H., Tushman, M.L., Smith, W., Anderson, P. (2002). A Structural Approach to Assessing Innovation: Construct Development of Innovation Locus, Type, and Characteristics. Management Science, 48(9), 1103-1123. https://doi.org/10.1287/mnsc.48.9.1103.174.

37.Gorynia, M., Trąpczyński, P., Bytniewski, S. (2019). The Concepts of Strategy and Business Models in Firm Internationalization Research: Towards a Research Agenda. International Entrepreneurship Review, 5(2), 7-21. https://doi.org/10.15678/ier.2019.0502.01.

38.Gorynia, M. (2019). Competition and Globalisation in Economic Sciences. Selected Aspects. Economics and Business Review, 5(3), 118-133. https://doi.org/10.18559/ebr.2019.3.7.

39.Govindarajan, V., Kopalle, P.K. (2006). Disruptiveness of Innovations: Measurement and an Assessment of Reliability and Validity. Strategic Management Journal, 27(2), 189-199. https://doi.org/10.1002/smj.511.

40.Gutting, G. (2017). Scientific Methodology. In W.H. Newton-Smith, John Wiley \& Sons (Ed.) $A$ Companion to the Philosophy of Science. https://doi.org/10.1002/9781405164481.ch63.

41.Hatchuel, A. (2005). Towards an Epistemology of Collective Action: Management Research as a Responsive and Actionable Discipline. European Management Review, 2(1), 36-47. https://doi.org/10.1057/palgrave.emr.1500029. 
42.Iansiti, M., Lakhani, K. (2014). Digital ubiquity: How connections, sensors, and data are revolutionizing business. Harvard Business Review, 92(11), 90-99. Available at: https://hbr.org/2014/11/digital-ubiquityhow-connections-sensors-and-data-are-revolutionizing-business.

43.Kharazishvili, Y., Kwilinski, A., Grishnova, O., \& Dzwigol, H. (2020). Social Safety of Society for Developing Countries to Meet Sustainable Development Standards: Indicators, Level, Strategic Benchmarks (with Calculations Based on the Case Study of Ukraine). Sustainability, 12(21), 8953. https://doi.org/10.3390/su12218953.

44.Klimas, P., Czakon, W., Kraus, S., Kailer, N., Maalaoui, A. (2020). Entrepreneurial Failure: A Synthesis and Conceptual Framework of its Effects. European Management Review, 1-16, https://doi.org/10.1111/emre.12426.

45.Kwilinski, A. (2017). Development of Industrial Enterprise in the Conditions of Formation of Information Economics. Thai Science Review, 85-90. https://doi.org/10.5281/zenodo.1414236.

46.Kwilinski, A. (2018a). Trends of Development of the Information Economy of Ukraine in the Context of Ensuring the Communicative Component of Industrial Enterprises. Economics and Management, 1(77), 64-70. Available at: https://e-u.in.ua/journal/792.pdf.

47.Kwilinski, A. (2018b). Mechanism of Formation of Industrial Enterprise Development Strategy in the Information Economy. Virtual Economics, 1(1), 7-25. https://doi.org/10.34021/ve.2018.01.01(1).

48.Kwilinski, A. (2018c). Mechanism of Modernization of Industrial Sphere of Industrial Enterprise in Accordance with Requirements of the Information Economy. Marketing and Management of Innovations, 4, 116-128. http://doi.org/10.21272/mmi.2018.4-11.

49.Kwilinski, A. (2019). Implementation of Blockchain Technology in Accounting Sphere. Academy of Accounting and Financial Studies Journal, 23(SI2), 1-6. Available at: https://www.abacademies.org/articles/Implementation-of-Blockchain-Technology-in-Accounting-Sphere1528-2635-23-SI-2-412.pdf.

50.Kwilinski, A., Dalevska, N., Kravchenko, S., Hroznyi, I., Kovalenko, I. (2019c). Formation of the Entrepreneurship Model of E-Business in the Context of the Introduction of Information and Communication Technologies. Journal of Entrepreneurship Education, 22(SI1), 1-7. Available at: https://www.abacademies.org/articles/Formation-of-the-entrepreneurship-model-of-e-business-in-15282651-22-S1-337.pdf.

51.Kwilinski, A., Ruzhytskyi, I., Patlachuk, V., Patlachuk, O., Kaminska, B. (2019d). Environmental Taxes as a Condition of Business Responsibility in the Conditions of Sustainable Development. Journal of Legal, Ethical and Regulatory Issues, 22(SI2), 1-6. Available at: https://www.abacademies.org/articles/Environmental-taxes-as-a-condition-of-business-responsibility-inthe-conditions-of-sustainable-development-1544-0044-22-SI-2-354.pdf.

52.Kwilinski, A., Volynets, R., Berdnik, I., Holovko, M., Berzin, P. (2019e). E-Commerce: Concept and Legal Regulation in Modern Economic Conditions. Journal of Legal, Ethical and Regulatory Issues, 22(SI2), 1-6. Available at: https://www.abacademies.org/articles/E-Commerce-concept-and-legal-regulation-in-moderneconomic-conditions-1544-0044-22-SI-2-357.pdf.

53.Kwilinski, A., Vyshnevskyi, O., Dzwigol, H. (2020). Digitalization of the EU Economies and People at Risk of Poverty or Social Exclusion. Journal of Risk and Financial Management, 13(7), https://doi.org/10.3390/jrfm13070142.

54.Kwilinski, A., Dzwigol, H., Dementyev, V. (2020). Model of Entrepreneurship Financial Activity of the Transnational Company Based on Intellectual Technology. International Journal of Entrepreneurship, 24(1). Available at: https://www.abacademies.org/articles/Model-of-Entrepreneurship-Financial-Activityof-the-Transnational-Company-Based-on-Intellectual-Technology.pdf.

55.Kyrylov, Y., Hranovska, V., Boiko, V., Kwilinski, A., \& Boiko, L. (2020). International Tourism Development in the Context of Increasing Globalization Risks: On the Example of Ukraine's Integration into the Global Tourism Industry. Journal of Risk and Financial Management, 13(12), 303. https://doi.org/10.3390/jrfm13120303.

56.Lakhno, V., Malyukov, V., Bochulia, T., Hipters, Z., Kwilinski, A., Tomashevska, O. (2018). Model of Managing of the Procedure of Mutual Financial Investing in Information Technologies and Smart City Systems. International Journal of Civil Engineering and Technology, 9(8), 1802-1812. Available at: http://www.iaeme.com/MasterAdmin/Journal_uploads/IJCIET/VOLUME_9_ISSUE_8/IJCIET_09_08_1 $\underline{81 . p d f}$.

57.Lenka, S., Parida, V., Wincent, J. (2017). Digitalization capabilities as enablers of value co-creation in servitizing firms. Psychology \& Marketing, 34(1), 92-100. https://doi.org/10.1002/mar.20975. 
58.Lyulyov, O., Pimonenko, T., Kwilinski, A., Dzwigol, H., Dzwigo-Barosz, M., Pavlyk, V., Barosz, P. (2021). The Impact of the Government Policy on the Energy Efficient Gap: The Evidence from Ukraine. Energies, 14(2), 373. https://doi.org/10.3390/en14020373.

59.Mårtensson, P., Fors, U., Wallin, S.-B., Zander, U., Gunnar Nilsson, G.H. (2016). Evaluating research: A multidisciplinary approach to assessing research practice and quality. Research Policy, 45(3), 593-603. https://doi.org/10.1016/i.respol.2015.11.009.

60.Miśkiewicz, R. (2018). The Importance of Knowledge Transfer on the Energy Market. Polityka Energetyczna, 21(2), 49-62. http://dx.doi.org/10.24425\%2F122774.

61.Miśkiewicz, R. (2019). Challenges Facing Management Practice in the Light of Industry 4.0: The Example of Poland. Virtual Economics, 2(2), 37-47. https://doi.org/10.34021/ve.2019.02.02(2).

62.Miśkiewicz, R. (2020a). Internet of Things in Marketing: Bibliometric Analysis. Marketing and Management of Innovations, 3, 371-381. http://doi.org/10.21272/mmi.2020.3-27.

63.Miskiewicz, R. (2020b). Efficiency of Electricity Production Technology from Post-Process Gas Heat: Ecological, Economic and Social Benefits. Energies, 13(22), 6106. https://doi.org/10.3390/en13226106.

64.Miśkiewicz, R., Wolniak, R. (2020). Practical Application of the Industry 4.0 Concept in a Steel Company. Sustainability, 12(14), 5776. https://doi.org/10.3390/su12145776.

65.Neuman, W.L. (2006). Social Research Methods: Qualitative and Quantitative Approaches 6th Edition. Pearson International Edition, USA. 594 p. Available at: http://letrunghieutvu.yolasite.com/resources/wlawrence-neuman-social-research-methods -qualitative-and-quantitative-approaches-pearson-educationlimited-2013.pdf.

66.Pająk, K., Kamińska, B., Kvilinskyi, O. (2016). Modern Trends of Financial Sector Development under the Virtual Regionalization Conditions. Financial and Credit Activity: Problems of Theory and Practice, 2(21), 204-217. https://doi.org/10.18371/fcaptp.v2i21.91052.

67.Pająk, K., Kvilinskyi, O., Fasiecka, O., Miskiewicz, R. (2017). Energy security in regional policy in Wielkopolska region of Poland. Economics and Environment, 2(61), 122-138. Available at: https://www.ekonomiaisrodowisko.pl/uploads/eis\%2061/11_pajak.pdf.

68.Porter, M.E., Heppelmann, J.E. (2015). How smart, connected products are transforming companies. Harvard Business. Review, 93, 97-114. Available at: https://hbr.org/2015/10/how-smart-connectedproducts-are-transforming-companies.

69.Quach, S., Thaichon, P., Lee, J.Y., Weaven, S., \& Palmatier R.W. (2019). Toward a theory of outside-in marketing: Past, present, and future. Industrial Marketing Management, 89, 107-128. https://doi.org/10.1016/j.indmarman.2019.10.016.

70.Queiros, A., Faria, D., Almeida F. (2017). Strengths and limitations of qualitative and quantitative research methods. European Journal of Education Studies, 3(9), 369-387. https://doi.org/10.5281/zenodo.887089.

71.Reisman, F. (2011). Creative, critical thinking and logic in research. RGUHS J Pharm Sci., 1, 97-102. Available at: https://www.yumpu.com/en/document/view/3320477/creative-critical-thinking-and-logic-inresearch-journal.

72.Saługa, P.W., Szczepańska-Woszczyna, K., Miśkiewicz, R., Chłąd, M. (2020). Cost of Equity of CoalFired Power Generation Projects in Poland: Its Importance for the Management of Decision-Making Process. Energies, 13(18), 4833. https://doi.org/10.3390/en13184833.

73.Savchenko, T., Basiurkina, N., Rodina, O., Kwilinski, A. (2019). Improvement of the Assessment Methods of Product Competitiveness of the Specialized Poultry Enterprises. Management Theory and Studies for Rural Business and Infrastructure Development, 41(1), 43-61. https://doi.org/10.15544/mts.2019.05.

74.Shrivastava, P. (1987). Rigor and Practical Usefulness of Research in Strategic Management. Strategic Management Journal, 8(1), 77-92. https://doi.org/10.1002/smj.4250080107.

75.Szcucka, K. (2010). Polski kwestionariusz perfekcjonizmu adaptacyjnego i dezadaptacyjnego [The Polish Adaptive and Maladaptive Perfectionism Questionnaire], Psychologia Spoleczna, 5(13), 71-95. Available at: http://czasopismo.badania.net/wp-content/uploads/2016/11/Szczucka PS 2010_1.pdf.

76.Terpstra, D.E. (1982). Evaluating selected organization development interventions: The state of the art. Group \& Organization Management, 7(4), 402-417. https://doi.org/10.1177/105960118200700404.

77.Tkachenko, V., Kwilinski, A., Korystin, O., Svyrydiuk, N., Tkachenko, I. (2019a). Assessment of Information Technologies Influence on Financial Security of Economy. Journal of Security and Sustainability, 8(3), 375-385. http://doi.org/10.9770/jssi.2019.8.3(7).

78.Tkachenko, V., Kwilinski, A., Klymchuk, M., Tkachenko, I. (2019b). The Economic-Mathematical Development of Buildings Construction Model Optimization on the Basis of Digital Economy. Management Systems in Production Engineering, 27(2), 119-123. http://doi.org/10.1515/mspe-2019-0020. 
79.Tkachenko, V., Kwilinski, A., Tkachenko, I., Puzyrova, P. (2019c). Theoretical and Methodical Approaches to the Definition of Marketing Risks Management Concept at Industrial Enterprises. Marketing and Management of Innovations, 2, 228-238. http://doi.org/10.21272/mmi.2019.2-20.

80.Tkachenko V., Kwilinski A., Kaminska B., Tkachenko I., Puzyrova P. (2019d). Development and Effectiveness of Financial Potential Management of Enterprises in Modern Conditions. Financial and Credit Activity: Problems of Theory and Practice, 3(30), 85-94. https://doi.org/10.18371/fcaptp.v3i30.179513.

81.Trąpczyński, P., Gorynia, M., Nowak, J., Wolniak, R. (2019). EU Countries from Central and Eastern Europe, and the Investment Development Path Model: A New Assessment. Argumenta Oeconomica, 2(43), 385-406. https://doi.org/10.15611/aoe.2019.2.16.

82.Venkatraman, N., Grant, J.H. (1986). Construct Measurement in Organizational Strategy Research: A Critique and Proposal. Academy of Management Review, 11(1), 71-87. https://doi.org/10.2307/258332.

83.Woodman, R.W., Wayne, S.J. (1985). An Investigation of Positive -Findings Bias in Evaluation of Organization Development Interventions. Academy of Management Journal, 28(4), 889-913. https://doi.org/10.2307/256243.

84.Imran, M., Waseem, H., and Adnan, H. (2018). Influence of Industry 4.0 on the Production and Service Sectors in Pakistan: Evidence from Textile and Logistics Industries. Social Sciences, 7, 246. https://doi.org/10.3390/socsci7120246.

85.Rüßmann, M., Lorenz, M., Gerbert, P., Waldner, M., Justus, J., Engel, P., Harnisch, M. (2015). Industry 4.0: The Future of Productivity and Growth in Manufacturing Industries. Boston, Massachusetts, United States: Boston Consulting Group. Available at: https://imagesrc.bcg.com/Images/Industry 40 Future of Productivity April 2015 tcm9-61694.pdf.

86.Waschneck, B., Altenmüller, T., Bauernhansl, T., Kyek, A. (2016). Production Scheduling in Complex Job Shops from an Industry 4.0 Perspective: A Review and Challenges in the Semiconductor Industry. Paper presented at the SAMI40 workshop at i-KNOW, Graz, Austria, October 18-19. Available at: http://ceurws.org/Vol-1793/paper3.pdf.

87.Weick, K.E. (1989). Theory construction as disciplined imagination. The Academy of Management Review, 14(4), 516-531. https://doi.org/10.2307/258556.

88.Zastempowski, M., Glabiszewski, W., Krukowski, K., Cyfert, S. (2020). Technological Innovation Capabilities of Small and Medium-Sized Enterprises. European Research Studies, 23(3), 460-474. https://doi.org/10.35808/ersj/1650. 